\title{
Land application of sewage sludge (biosolids) in Australia: risks to the environment and food crops
}

\author{
D. L. Pritchard ${ }^{1}$, N. Penney ${ }^{2}$, M. J. McLaughlin ${ }^{3}$, H. Rigby ${ }^{1}$ \& K. Schwarz ${ }^{1,4}$ \\ ${ }^{1}$ Curtin University of Technology, Muresk Campus, PMB 1, Northam, Western Australia 6401, Australia (E-mail: \\ d.pritchard@curtin.edu.au ) \\ ${ }^{2}$ Water Corporation, Leederville, Western Australia, Australia. \\ ${ }^{3}$ Centre for Environmental Contaminants, CSIRO Land and Water, Adelaide, South Australia, Australia. \\ ${ }^{4}$ CSIRO Land and Water, Queensland Biosciences Precinct, St Lucia, Brisbane, Queensland, Australia.
}

\begin{abstract}
Australia is a large exporter of agricultural products with producers responsible for a range of quality assurance programs to ensure that food crops are free from various contaminants of detriment to human health. Large volumes of treated sewage sludge (biosolids), although low by world standards are increasingly being recycled to land; they are used in agriculture, forestry, and composted for use in horticulture primarily to replace plant nutrients and to improve soil properties. This paper summarises the major issues and constraints related to biosolids use in Australia using specific case examples from Western Australia, a member of the Australian National Biosolids Research Program (NBRP), and highlights the main research conducted over the last decade to ensure that biosolids are used beneficially and safely in the environment. Attention is given to research relating to nutrient uptake, particularly nitrogen and phosphorus (including that of reduced phosphorus uptake in alum biosolids-amended soil); the risk of heavy metal uptake by plants, specifically cadmium, copper and zinc; the risk of pathogen contamination in soil and grain products; change to soil pH (particularly following lime-amended biosolids); and the monitoring of faecal contamination by biosolids in waterbodies using DNA techniques. Biosolids that are currently produced in Western Australia include mesophilic anaerobically digested and dewatered biosolids cake, lime-amended biosolids, alum biosolids and, previously produced pelletised biosolids and char via pyrolysis. The use of biosolids in Western Australia is strictly regulated by the 'Western Australian Guidelines for Direct Land Application of Biosolids and Biosolids Products 2002', which is currently being revised following research outcomes. Throughout Australia, the Australian National Biosolids Research Program has linked researchers with a common goal to investigate nutrients and benchmark safe concentrations of metals nationally using a common methodology, with research programs conducted in a number of other states specific to regional problems and priorities. Further work presented at this conference will highlight the importance in Australia of nitrogen issues (Rigby et al.), guideline and policy issues (Penney et al.) and the role of the Australasian Biosolids Partnership (ABP) (Speers et al.).
\end{abstract}

Keywords: Dewatered biosolids cake (DBC); lime amended biosolids (LAB); alum biosolids (AB); pathogens; agriculture; forestry; composting

\section{Introduction}

In Australia, the secondary treatment of sewage sludge is common, with a unanimous view amongst state regulators in the short and medium term to manage the stabilised sludge (biosolids) in a beneficial way to take advantage of nutrients and desirable soil enhancing properties; though in the long term newer technology and economic drivers may dictate future trends (Dixon and Anderson, 2007). Currently, the end-use of biosolids varies in each state, as determined by state water industries, the quality of the product and available options for disposal, but commonly includes agricultural land application, forestry, composting and blending with other products, mine-site rehabilitation, stockpiling, landfill or incineration for energy recovery. Overall the quantity of biosolids produced in Australia (360,000 dry tones $\mathrm{yr}^{-1}$ ) is low by world standards and furthermore produced in a continent with relatively low population density, but nevertheless the management is subject to much public scrutiny (Gale, 2007).

Large centralised wastewater treatments plants are a relatively recent development in the history of Australia. 
For example, in Western Australia, the discharge of sewage sludge into the Swan River ceased in the mid 1900s as a means to prevent water pollution. In the 1970s, the benefits of sewage sludge as a soil amendment and nutrient source were exploited by market gardeners, who collected dried sewage sludge from drying ponds for vegetable production. Associated health risks, however, in the late 1980s led to the construction of three incinerators to handle a large proportion of the sludge, but by 1990 all three units were shut down due to high costs and odour issues. During this period, the sludge was also used in compost or landfilled. A number of problems associated with sludge drying beds, such as lack of space, odours, flies and risks to groundwater contamination, resulted in them being progressively decommissioned. As a result, wastewater treatment plants were amplified or, in some cases, newly constructed to process sludge and to use established processes to achieve stabilisation and significant pathogen reduction.

At present, the two major wastewater treatment plants (WWTPs) in capital of Western Australia (Perth) stabilise sludge by mesophilic anaerobic digestion and then use enclosed centrifuges to rapidly dewater the sludge to $20 \%$ total solids, with discharge of effluent via outfalls to the ocean. The third major WWTP currently stabilises raw sludge by the addition of lime, although previously it produced pelletised biosolids by thermal drying (Bridle et al., 2000) using an indirect rotary drum dryer, with pellets used for energy recovery at the plant. The smaller inland towns in rural Western Australia consist of smaller WWTPs, which often discharge to inland waterbodies, therefore it is common to dose the sludge with alum $\left(\mathrm{Al}_{2}\left(\mathrm{SO}_{4}\right)_{3}\right)$ to reduce the concentration of phosphorus in effluent that is discharged to waterways. There are a number of independent regional water authorities throughout Australia. The Water Corporation is the sole industry responsible for managing wastewater treatment facilities in both metropolitan and rural regions within Western Australia.

Almost all of the 40,000 dry t of biosolids produced annually in the metropolitan area in Western Australia have been beneficially reused for the last several years, with the three main outlets being direct land applications to agriculture and forestry (80\%), unrestricted product via composting (17\%) and research (3\%). The composting of biosolids with other materials for horticultural use has been practiced for many years, although the widespread land application of dewatered biosolids cake in agriculture and forestry has been more recent (1996). In general, the response by farmers has been positive, with participating farmers referring to the biosolids as 'black gold' due to the improvement in productivity to their grain and oilseed crops and consequent income, though resistance to land application is expressed by a small minority. In forestry, biosolids applied to established pine plantations showed significant improvement in tree growth compared to inorganic fertiliser application. Where biosolids are applied to land, they are governed by a national regulatory framework and state guidelines to ensure minimal risks to the environment and the community (NRMMC, 2004). Preliminary research investigations in eastern Australia during the 1990s, using data from overseas, gave rise to guidelines on one state of Australia (NSW EPA, 1997) that were subsequently used as a basis for biosolids application throughout Australia. These consequently led to the development of guidelines for Western Australia (DEP et al. 2002), which are in the process of being further updated on the basis of more recent research described below.

This paper will discuss the main research programs conducted in Western Australia to assess the suitability and risk of biosolids relating to the direct land application for food production, including its role in the Australian National Biosolids Research Program (NBRP). Research programs over the last decade have examined nutrient availability (predominantly nitrogen and phosphorus), effect on soil acidity, bioavailability of heavy metals, the risk of pathogen transfer, and methods for detection of faecal contamination over a range of biosolids products, including dewatered biosolids cake, lime-amended biosolids, pelletised biosolids and alum biosolids.

\section{Research programs relating to the beneficial use of biosolids}

\subsection{Research on plant nutrients}

Land in Australia has only been used for broad-scale farming over the last200 years. Many of the soils are highly weathered, environmentally fragile with low organic matter and are often sandy, infertile and acidic (Moore, 2002). Therefore, to achieve productivity, regular applications of fertiliser are required to replace plant nutrients removed in produce and managed to improve organic matter, with a recent trend to investigate the fertilizer value of various waste products. The Australian National Biosolids Research Program (NBRP) was established by the CSIRO in Australia in 2002 to co-ordinate research relating to the benefits and risks of using biosolids in agriculture (McLaughlin et al., 2007b). The impetus to investigate the use biosolids in agriculture arose at a time when other options for long term disposal of sewage, such as landfill and ocean discharge, were considered the least environmentally sustainable. The two main plant nutrients in biosolids, nitrogen $(\mathrm{N})$ and phosphorus $(\mathrm{P})$ have consequently been investigated as a substitute for 
commercially applied fertilizer. Final loading rates in Australia have typically been determined by estimating the amount of plant available $\mathrm{N}$ in the biosolids and the crop nutrient uptake requirement for $\mathrm{N}$, often termed the nitrogen limited biosolids application rate (NLBAR) (DEP et al., 2002). At the majority of sites throughout Australia, the application of biosolids had a positive effect on crop yields (McLaughlin et al., 2007b). In Western Australia, the NLBAR has been estimated to be approximately $8 \mathrm{t} \mathrm{DS} \mathrm{ha-1}$ for wheat in dryland agriculture, equivalent to $70 \mathrm{~kg}$ of plant available $\mathrm{N} \mathrm{ha}{ }^{-1}$, with grain yield of wheat at the NLBAR comparable to yields obtained using farmer rates of commercial inorganic fertilizer in the year of application (Pritchard and Collins, 2006). The NLBAR may be higher in other regions, such as sub-tropical Queensland where crop requirements for $\mathrm{N}$ are higher (Barry and Bell, 2006). The NLBAR has assumed that $10-25 \%$ of the organic $\mathrm{N}$ in biosolids is mineralized in the first year, though recent research in Queensland and Western Australia indicate this to be higher. A problem with underestimating $\mathrm{N}$ mineralization is that excess $\mathrm{N}$ may enter water bodies through runoff and/or leaching and lead to eutrophication of water bodies and/or gaseous losses contributing to greenhouse emissions. Further research on the efficiency of $\mathrm{N}$ in a range of biosolid products is presented by Rigby et al. at this conference.

A concern of using the NLBAR to determine land application rates is that the loading rate of $\mathrm{P}$ is higher than typically applied through a commercial fertiliser application. In Australia, for example, loading rates of $\mathrm{P}$ in biosolids can range from 140 to $560 \mathrm{~kg} \mathrm{P} \mathrm{ha}^{-1}$ at any one site, in contrast to typical inorganic fertiliser $\mathrm{P}$ applications of around $20 \mathrm{~kg}$ $\mathrm{P} \mathrm{ha}^{-1}$, and therefore best agronomic management practices need be used to prevent environmental problems (Pritchard et al., 2007). There are differences, however between $P$ applied as inorganic P fertiliser or applied as biosolids P. Biosolids contain between $90-95 \%$ inorganic forms of $\mathrm{P}$ (Bell and Barry, 2006), are less soluble than inorganic $\mathrm{P}$ fertiliser, and in dryland broadacre agriculture are approximately $67 \%$ as effective as inorganic $\mathrm{P}$ fertiliser (Pritchard, 2005). Consequently, the relatively high loading rates of biosolids $\mathrm{P}$ do not necessarily pose a problem on many soil types, for example, $\mathrm{P}$ deficient soils with high $\mathrm{P}$ sorbing properties are at low risk of $\mathrm{P}$ leaching. Consequently the $\mathrm{P}$ limiting biosolids application rate (PLBAR) is largely less restrictive than $\mathrm{N}$ loading rates and largely determined by soil properties (Pritchard and Penney, 2003). There is a need to further examine in detail the fate of P in many of the agricultural sites common to the NBRP using the database of information available, particularly given the finite nature of $\mathrm{P}$ as a dwindling resource. Alternatively, options to reduce the discharge of $\mathrm{P}$ in effluent needs further investigation, such as through struvite recovery or similar.

\subsection{Heavy metals (copper, zinc and cadmium)}

The NBRP was responsible for investigating the solubility of metals of environmental importance in biosolids, namely cadmium (Cd), copper (Cu) and zinc (Zn), and comparing these to metal salts across a range of sites and environmental conditions throughout Australia. State research units existed in New South Wales, South Australia, Queensland, Victoria and Western Australia (Figure 1).

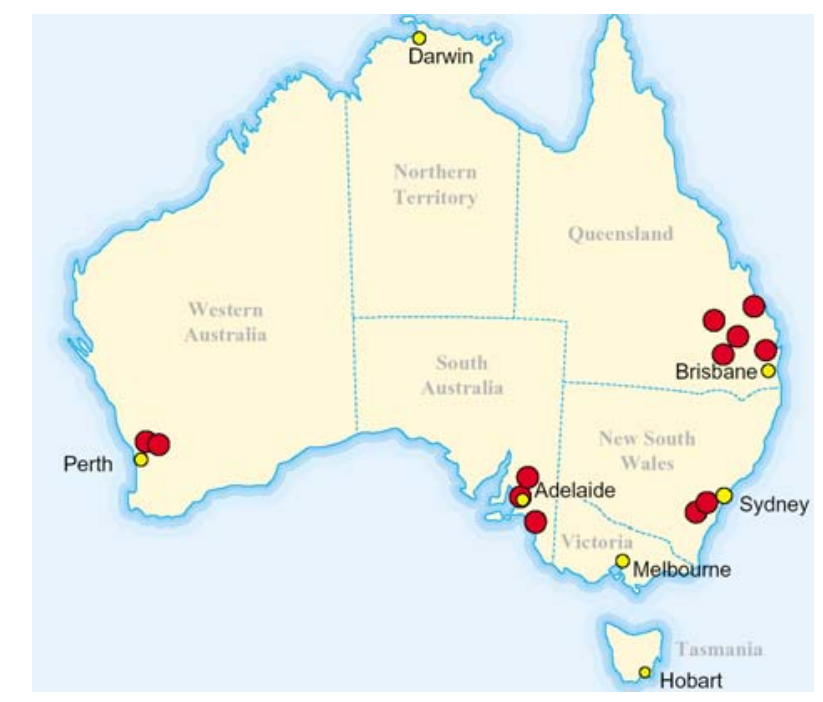

Figure 1 Locations of field experiments in the Australian National Biosolids Research Program (from McLaughlin et al., 2007a).

A common experimental methodology was used by each state research group applying biosolids products at multiples of the NLBAR, and metal salts, with the highest rates designed to induce phytotoxicity in plants. A number of publications have arisen in response to the research findings that characterize how metals in biosolids behave across the diverse soils and environmental conditions throughout Australia, e.g. in McLaughlin et al. (2006; 2007a) and Heemsbergen et al. (2009); these outcomes can be considered by regulators and industry for changing regulatory guidelines. A major finding was that that grain Cd concentrations grown on biosolids-amended soils were below the current food standard of $0.1 \mathrm{mg} \mathrm{kg}^{-1}$ (wheat), even when biosolids were applied in excess of crop $\mathrm{N}$ requirement, though uptake varied depending on soil type. 
To take account of different soil types and solubility principles of Cd, McLaughlin et al. (2007a) suggested that the single protective maximum soil concentration for $\mathrm{Cd}$ (1.0 mg Cd kg-1) was problematic and the maximum permitted $\mathrm{Cd}$ concentration be more restrictive $(0.3 \mathrm{mg} \mathrm{Cd}$ $\mathrm{kg}^{-1}$ ) in acidic sands and less restrictive in heavier soil types (2.6 mg Cd kg-1) to ensure wheat grain would not exceed Cd food standards.

Critical concentrations of $\mathrm{Cu}$ and $\mathrm{Zn}$ examined by the NBRP in terms of both the soil microbial activity and plant phytotoxicity response indicated that soil parameters such as $\mathrm{pH}$, cation exchange capacity (CEC) and clay content were main determinants in predicting microbial survival to soil concentrations of $\mathrm{Cu}$ and $\mathrm{Zn}$ (Broos et al., 2007), whereas soil pH, CEC and organic matter content were the main determinants in plant survival (Warne et al., 2008). Heemsbergen et al. (2009) explain the development of $\mathrm{Cu}$ and $\mathrm{Zn}$ added contaminant limits (ACL) for biosolids and conclude that the current single soil quality guidelines in Australia (100-200 mg Cu kg-1 and 200-250 mg Zn kg NRMMC, 2004) do not reflect different soil physiochemical properties and the authors hence propose a new framework for $\mathrm{Cu}$ and $\mathrm{Zn}$ to protect $95 \%$ of species. However, even on acidic sands, the most vulnerable soils for metal phytotoxicity and food chain hazards, biosolids applied at 4.5 times the recommended rates (based on $\mathrm{N}$ ), soil concentrations in the surface $(0-10 \mathrm{~cm})$ were below the maximum allowable soil contaminant concentration (MACC) of metals such as $\mathrm{Cd}, \mathrm{Cu}$ and $\mathrm{Zn}$ (Pritchard \& Collins, 2006). Many Australian biosolids are typically domestic in origin and therefore have a low industrial trade waste input, which is reflected in the lower metals concentrations compared to many sludges produced elsewhere in industrialized nations.

\subsection{Lime-amended biosolids (LAB)}

The production of lime-amended biosolids is restricted to a few WWTPs in Australia and often as a short term solution to sludge stabilization. Subiaco WWTP (Western Australia) applies quicklime $(\mathrm{CaO})$ post-treatment to secondary treated dewatered sludge cake to raise the $\mathrm{pH}$ of the mixture and destroy pathogens. The land application of LAB is comparable to equivalent amounts of agricultural lime in neutralizing soil acidity, though the main benefit for crop growth appears to be from the nutrient value of the recycled nutrients (typically $\mathrm{N}$ and $\mathrm{P}$ ) (Pritchard et al., 2008). Consideration needs to be given to the Plant Available Nitrogen (PAN) value of LAB compared to DBC when calculating effective $\mathrm{N}$ application rates (see Rigby et al. this conference).

\subsection{Alum biosolids (AB)}

Many rural wastewater treatment facilities use alum dosing $\left(\mathrm{Al}_{2}\left(\mathrm{SO}_{4}\right)_{3}\right)$ as a means of phosphorus removal in the effluent, which is a government licence requirement to minimise the pollution of inland waterways with $\mathrm{P}$. The alum when added to the wastewater treatment process, forms a precipitate and is removed with the sludge. The alum sludge has typically been landfilled in Australia due to the paucity of information on the effects of alum on plant and soil health. Recent investigations by Rigby et al. (2008), however, indicate that crop production can be achieved using alum biosolids (7\% $\mathrm{Al})$, although a reduction in shoot uptake of $\mathrm{P}$ was evident and is under further investigation. There has been a limited amount of research into land application of alum biosolids (AB) elsewhere, however, stabilisation of biosolids with alum or iron sulphate has been promoted as a method of preventing $\mathrm{P}$ loss from biosolids-amended soils (Huang et al., 2007). For the same reasons the benefits of co-application of biosolids with water treatment residuals (WTR) following alum dosing have been investigated (Ippolito et al., 2002; Ippolito et al., 2006; Agin-Birikorang et al., 2008; Wagner et al., 2008), and this research has generally indicated a reduction in $\mathrm{P}$ availability on treated soils.

\subsection{Forestry}

Forestry plantations are a large potential market for biosolids use in Western Australia with 5,500 ha of softwood plantations available for the application of biosolids, with fertiliser management commonly including the application of inorganic fertilisers of $\mathrm{N}$ and $\mathrm{P}$ at various stages throughout the rotation. Dumbrell and McGrath (2002) investigated the response of pines to the application of dewatered biosolids cake (DBC) in a 17 year-old Pinus pinaster plantation on deep sand in a $920 \mathrm{~mm} \mathrm{yr}^{-1}$ rainfall area. The experiment included a control, standard mineral fertiliser (500 kg ha ${ }^{-1}$ di-ammonium phosphate $+250 \mathrm{~kg}$ $\mathrm{ha}^{-1}$ urea) and two rates of biosolids (17 and $34 \mathrm{t} \mathrm{DS} \mathrm{ha}^{-1}$ ). Compared with the nil fertiliser control, the mineral fertiliser and both biosolids treatments initially increased the tree volume increment by $19 \%, 27 \%$ and $55 \%$, respectively, over three years $\left(2 \mathrm{~m}^{3} \mathrm{ha}^{-1} \mathrm{yr}^{-1}, 3 \mathrm{~m}^{3} \mathrm{ha}^{-1} \mathrm{yr}^{-1}\right.$, $6 \mathrm{~m}^{3} \mathrm{ha}^{-1} \mathrm{yr}^{-1}$ ). The mineral fertiliser treatment produced the largest volume increment in the first year only relative to the control treatment. Relative volume increments in the biosolids treatments increased greatly in the second year and continued to increase in the third year, while the response in the mineral fertilizer treatment was constant and then declined. Biosolids applied at 34 t DS significantly 
increased foliar concentrations of $\mathrm{N}, \mathrm{P}, \mathrm{Zn}$ and manganese (Mn) above all other treatments over three years. Both the mineral fertiliser treatment and biosolids treatment at $17 \mathrm{t}$ DS significantly increased foliar concentrations of $\mathrm{N}$ for two years and $\mathrm{P}$ for three years above the control treatment. Dumbrell (2006) showed that eight years after start of the experiment, the trees in the biosolids treatments continued to grow at a faster rate than the trees in both the nil and mineral fertiliser treatments, with the longevity of response yet to be determined. Surface soil $(0-10 \mathrm{~cm})$ samples and groundwater did not detect any indication of pathogens (thermo-tolerant coliforms or salmonella), pesticides, and total $\mathrm{N}$ or $\mathrm{P}$ from any treatment. Concentrations of heavy metals in the $0-10 \mathrm{~cm}$ surface soil were below the DEP et al. (2002) guidelines. The mineral fertiliser treatment was the only treatment to significantly $(\mathrm{P} \leq 0.05)$ increase bicarbonate extractable $\mathrm{P}$ in the surface soil after treatment. Concentrations of nitrate in groundwater remained unchanged in samples taken from bores within the plantation, though levels of nitrate were excessive beneath stockpiles on biosolids outside the study area (Dumbrell and $\mathrm{M}^{\mathrm{C}} \mathrm{Grath}$, 2003). The major constraints identified from this study relate to the high cost of transport and application, on site storage provisions, and the time required for stockpiling and application. The minor constraints were related to the social aspects, such as odour and public access, and the required operational condition of the plantation.

\subsection{Composting}

A number of private companies further process biosolids and produce products suitable for use in domestic markets. In the Perth region (Western Australia) for example, approximately 2,400 $\mathrm{t}$ DS $\mathrm{yr}^{-1}$ of $\mathrm{DBC}$ is transported direct from WWTPs, with a further $500 \mathrm{t}$ DS at $17 \%$ DS sourced from a temporary biosolids stockpile, which is slowly being depleted. Until recently the percentage of compost being utilised in areas such as horticulture and turf was minimal, however with changes to the availability of raw materials such as chicken manure, this market is also expanding.

There are many methods available for composting and blending material to produce a product that meets the market demands. However, the typical composting process consists of: initial blending of raw materials, windrowing to control temperature, and mixing and final blending. During the first stage, biosolids are blended with other products such as sawdust and green waste, which is windrowed for approximately 10 to 16 weeks, during which time the rows are turned at least twice a week. Once the biosolids compost has met the unrestricted use requirement (DEP et al., 2002), aliquots of the mix are taken and depending on market demand are blended with peat, sand, loams or mulch.

\subsection{Reducing vectors in stockpiled biosolids and the centralised biosolids storage facility}

In Western Australia over the last decade, areas along the Swan Coastal Plain have reported excessive fly breeding. In particular, the blood-sucking stable fly (Stomoxys calcitrans) is of most concern as it breeds in organic mediums, including manures (Penney and Dadour, 2002). These fly epidemics have the potential to force the closure of the Water Corporation's current programs for beneficial reuse of biosolids, typically land applied throughout the agricultural region. Therefore, in 2002, the Water Corporation commenced a project to determine the attractiveness and breeding capacity of flies in DBC over 12-months and investigated the seasonal variation and response of fly breeding in fresh and aged DBC. The study identified the chemical and physical components that rendered biosolids attractive as a fly breeding medium by examining the relationship between the moisture level, $\mathrm{pH}$, the ammonia content and specific organic content; and correlated the above information to determine guidelines to prevent the breeding of flies. Covering the stockpiles during fly breeding season was the most effective control method and consequently was implemented in storage guidelines.

The building of a centralised biosolids storage facility (CBSF) has been developed by the Water Corporation to overcome the problems associated with fly breeding in stockpiled biosolids prior to land application, and alleviate on-site storage problems. There are limited facilities to store DBC at the WWTPs (150 to 300 t DS), with holding space only available for a maximum of 36 hours in overhead hoppers. Consequently biosolids will be transported daily to the CBSF by trucks from WWTPs and stored for a minimum of 30 days prior to spreading on agricultural properties. The facility is the first of its kind in Australia and has been designed to be vector proof to prevent the breeding of blood sucking flies, which lay eggs in the biosolids. Traditionally, biosolids were stockpiled in earthen bunds in paddocks close to spreading sites. It was possible to reduce fly breeding by reducing the stockpile time to less than 7 days, although not as practical as this option was dependant on land availability. Another problem with stockpiling biosolids includes the potential for nutrient rich leachate to contaminate groundwater. Fly breeding is not an issue in lime-amended biosolids because of the lower moisture content. 


\subsection{Pathogens}

The risk of pathogens transferring to cereal grains following the land application of dewatered biosolids cake has been investigated by Crute et al. (2005), with further experimental work continuing. The risk of pathogens surviving in the soil and transferring to grain would appear to be unlikely, with indicator microorganisms (Escherichia coli, Enterococci and bacteriophage) decreasing over time in the soil in both field and pot experiments following the application of DBC. Indicator bacteria were not detected on the lower leaves of the wheat plants sampled in the field 12 weeks after application at 1.5x NLBAR. In general, there were higher numbers of $E$. coli and Enterococci present in the root zones of plants than in the adjacent soil (i.e. two- $\log _{10}$ higher and one- $\log _{10}$ higher, respectively at week 15), although there were no significant differences between nil biosolids or biosolids treatments. There is a current investigation into the presence of indicator organisms, including Salmonella typhimurium, Escherichia coli, bacteriophage(MS2), adenovirus and Cryptosporidium at field sites in Western Australia and South Australia using a methodology including spiked soil samples containing biosolids and nil biosolids.

Constant monitoring of the quality of biosolids (contaminant and pathogen) produced by the Water Corporation show that some parameters are below detection limits. This has meant a less stringent monitoring program for the parameter listed in the guidelines, which has allowed the Corporation to focus on other potential contaminants such as dioxins and alkyl-phenols.

\subsection{Faecal contamination of waterways}

Increased nutrient levels in inland waterways have led to algal blooms and eutrophication in many agricultural regions. Point sources of pollution could include inorganic fertilisers, livestock excreta, or more recently biosolids. The presence of faecal indicator microorganisms has been widely used to identify the presence of faeces, however, these methods cannot distinguish between human and animals samples. With the aim of distinguishing biosolids from faeces of cattle, sheep, poultry and kangaroo, a molecular method using polymerase chain reaction (PCR) amplification was investigated using published priming sequences and restriction site profiling of amplified DNA across the 16S rRNA gene of anaerobic gastrointestinal bacteria Bacteroides spp. and Bifidobacteria spp. (Pritchard et al., 2008). Three Bacteroides sp. primer pairs were investigated with moderate success; two were useful for cow faecal materials though at lower annealing temperatures were also applicable to biosolids and sheep faecal material, whilst the third primer was specific only for biosolids. All three primer pairs were unable to PCR-amplify Bacteroides spp. sequences in faecal material of kangaroo. Of the three Bifidobacteria spp. primer pairs, one was useful for sheep faecal material, though at lower annealing temperature was also applicable to biosolids and cow and kangaroo faecal material. The Bifidobacterium angulatum specific primer pair enabled the PCR detection of anaerobes only in biosolids and faecal material of kangaroo. The third, a Bifidobacterium catenulatum specific primer pair was suitable for faecal material of cow and at lower annealing temperatures was also applicable to the sample from sheep. Varying degrees of success were observed in faecal material from other animals.

Generally, biosolids tested positive for Bacteroides and Bifidobacteria with all primers except for those specific for B. angulatum. For some primer sets, PCR amplification alone could not differentiate biosolids from other faecal samples. The serial dilution of water contaminated by a range of livestock excreta and biosolids is being examined further to enable the sensitivity of this method to be applied in the field.

\section{Conclusions}

A number of research programs across Australia have investigated the benefits and risks associated with the land application of biosolids for food production. The level of treatment of sewage sludge in Australia is generally high with government regulations in place concerning the quality of the biosolids and land application guidelines. The major issues relating to the land application of biosolids in Australia has been investigated as a coordinated approach by the Australian National Biosolids Research Program, involving several field experimental sites and a number of research organisations with the aim to ensure that biosolids pose minimal risks to public health and the environment. Research over the last decade has centered mostly on that of the benefits and risks of nutrients ( $\mathrm{N}$ and $\mathrm{P}$ ) and heavy metals $(\mathrm{Cd}, \mathrm{Cu}$ and $\mathrm{Zn})$, with a national approach ensuring that key outcomes could be used to derive regulations. Consideration has been given to the unique soil and climatic conditions in Australia. Individual states and researchers have been responsible for more localised research specific to their needs, and although not all presented in this paper, examples from Western Australia have illustrated major research activities in agriculture and forestry, with composting already established as a sound 
long-term market. The positive aspects of biosolids as a fertiliser and a soil amendment have created a demand for a resource, which has often been 'wasted'. Farmers have benefited from crop and soil improvement as a result of biosolids application, with a number of years of research data available to support this. Tree volume growth in pine plantations has increased significantly following biosolids application. The agricultural land application rates are being fine tuned to ensure biosolids loading rates consider both the nutrient needs of the crop and the environmental risks associated with the specific product (i.e. dewatered biosolids cake, lime-amended biosolids, alum biosolids). Continuing research is being conducted into the risk of pathogens to ensure the safety of public health. Techniques are being developed to better monitor the presence of faecal material in waterways using PCR methods. The fly breeding program has highlighted solutions to prevent the breeding of flies in biosolids and influenced the design of the Centralised Biosolids Storage Facility. The land application of biosolids is constantly subject to public scrutiny and therefore it is essential to have a sound research program to be scientifically accountable to ensure that the environment and public health are not being compromised by real or perceived risks.

\section{Acknowledgements}

The authors acknowledge the financial support of the Water Corporation and Curtin University of Technology, Western Australia. The authors would like to thank David Collins for his management of the various field experiments and the various State NBRP team members for their support over the duration of the project.

\section{References}

Agin-Birikorang S., O’Connor G., Oladeji O., Obreza T. and Capece J. (2008) Drinking-water treatment residual effects on the phosphorus status of field soils amended with biosolids, manure and fertiliser. Communications in Soil Science and Plant Analysis, 39, 1700-1719.

Barry G. and Bell M. (2006). Sustainable biosolids recycling in south east Queensland - a report to Brisbane Water. November 2006. Brisbane, Queensland, Australia.

Broos K., Warne M.St.J., Heemsbergen D.A., Stephens D.P., Barnes, M.B., and Correll R. (2007). Soil factors controlling the toxisity of $\mathrm{Cu}$ and $\mathrm{Zn}$ to microbial processes in Australian soils. Environmental Toxicology and Chemistry.

Bridle T.R., Molinari L., Skrypski-Mantle S., Ye D.P. and Mills J. (2000). Start-up of the Subiaco Enersludge ${ }^{\mathrm{TM}}$
Plant. Wat. Sci. Tech., 41(8), 31-36.

Crute K., Toze S., Pritchard D. and Penney N. (2005). 'Pathogens in biosolids: potential for survival following application in broadacre cropping crops'. Proceedings AWA Specialty Conference Contaminants of Concern in Water, Rydges Lakeside, Canberra, 22-23 June 2005, Australian Water Association.

Dixon D. and Anderson T. (2007). Australasia. In Spinos L. (Ed.) Watewater sludge: a global overview of the current status and future prospects. Water21 Market Briefing Series, IWA Publishing, London, UK.

DEP, WRC and DOH. (2002). Western Australian guidelines for direct land application of biosolids and biosolids products, Biosolids Working Group, Department of Environmental Protection (DEP), Waters and Rivers Commission (WRC), Department of Health (DOH), Perth, Western Australia.

Dumbrell I. (2006). Biosolids produce significant long-term growth increases in Western Australian pine plantations without adverse impacts. Proceedings: New Zealand Land Treatment Collective's $27^{\text {th }}$ Conference, March 14-17, Nelson, New Zealand.

Dumbrell I.C. and $\mathrm{M}^{\mathrm{C}}$ Grath J.F. (2002). Biosolids produce significant increases in growth and nutrient status in a Western Australian pine plantation without contamination of groundwater. Proceedings: "Biosolids Specialty Conference”, Sydney, June 19 20, 2002. Australian Water Association, Artarmon, New South Wales, Australia.

Dumbrell I.C. and $\mathrm{M}^{\mathrm{c}}$ Grath J.F. (2003). Plantation water use prevents contamination of groundwater following application of biosolids. Proceedings: "Innovations in Water" Ozwater Convention and Exhibition. Perth, Western Australia, April 6-10 2003. Australian Water Association, Artarmon, NSW.

Gale A. (2007) The Australasian Biosolids Partnership and Public Perceptions, in LeBlanc, R.J., Laughton, P.J. and Rajesh, T. (Eds). Proceedings Moving Forward, Wastewater Biosolids Sustainability: Technical, Managerial, and Public Synergy, International Water Association (IWA), Moncton, New Brunswick, Canada, 24-27 June 2007, pp 109-115..

Heemsbergen D.A., Warne M.St.J., Broos K., Bell M., Nash D., McLaughlin M., Whatmuff M., Barry G., Pritchard D. and Penney N. (2009). Application of phytotoxicity data to a new Australian soil quality guideline framework for biosolids. Science of the Total Environment, 407(8), 2546-2556.

Huang X.-L., Chen Y. and Shenker M. (2007). Solid phosphorus phase in aluminium- and iron-treated biosolids. Journal of Environmental Quality, 36, 549-546.

Ippolito J.A., Barbarick K.A. and Redente E.F. (2002). Combinations of water treatment residuals and biosolids affect two range grasses. Communications in Soil Science and Plant Analysis, 33, 831-844.

Ippolito J., Stromberger M., Barbarick K and Bayley R. (2006). Water Residuals and Biosolids: Effect of Co-Application on Soil Phosphorus. American Water 
Works Association. IWA, USA.

McLaughlin M.J., Whatmuff M., Warne M., Heemsbergen D., Barry G.., Bell M.J., Nash D., Pritchard D. and Penney N. (2007a). Predicting the risk from cadmium transfer to crops from soils amended with biosolids. Proceedings of the AWA Ozwater 2007 Convention and Exhibition. O7291. Sydney, New South Wales, Australia, Australian Water Association.

McLaughlin M.J., Warne M.St.J., Whatmuff M.S., Heemsbergen D., Broos K., Barry G.., Bell M.J., Nash D., Pritchard D. and Penney N. (2007b). Australia's National Biosolids Research Program- how it came about, and what has it discovered? Water Practice and Technology, 2(4), IWA Publishing doi:10.2166/WPT.2007088.

McLaughlin M.J., Whatmuff M.S., Warne M.St.J., Heemsbergen D., Barry G., Bell M.J., Nash D., Pritchard D. (2006). A field investigation of solubility and food chain accumulation of biosolids-cadmium across diverse soil types. Environmental Chemistry, 3, 428-432.

Moore G. (2002). (Ed.). Soil Guide: a handbook for understanding and managing agricultural soils, Bulletin 4343, Department of Agriculture, Western Australia.

NRMMC: Natural Resource Management Ministers Council. (2004). Guidelines for Sewerage Systems Biosolids Management. National Water Quality Management Strategy Paper 13, Canberra, Australia.

NSW EPA: New South Wales Environmental Protection Authority. (1997). Environmental Guidelines: Use and disposal of biosolids products. New South Wales Environmental Protection Authority, Sydney, Australia.

Penney N. and Dadour I. (2002). Biosolids and flies. Proceedings: Biosolids Specialty Conference I, June 19-20, 2002, Sydney, N.S.W, Australian Water Association.

Pritchard D., Collins D., Allen D. and Penney N. (2008) 'Land application of lime amended biosolids'. Proceedings Biosolids Specialty Conference IV, Australian Water Association, Adelaide, Australia, 11-12 June 2008 on CD-Rom, Paper 08.

Pritchard D., Davis J.A., Ho K.K.W. and Penney N. (2008), 'Monitoring of waterways for evidence of faecal contamination from biosolids using DNA techniques'. Proceedings Biosolids Specialty Conference IV, Australian Water Association, Adelaide, Australia, 11-12 June 2008 on CD-Rom, Paper 26.

Pritchard D., Penney N., Bell M. and Barry G. (2007) 'Getting a grip on biosolids; the impact of phosphorus loading rates in Australia', in LeBlanc R.J., Laughton P.J. and Rajesh T. (Eds). Conference Proceedings Moving Forward, Wastewater Biosolids Sustainability: Technical, Managerial, and Public Synergy, International Water Association (IWA), Moncton, New Brunswick, Canada, 24-27 June 2007, on CD-Rom, pp 853-859.

Pritchard D. and Collins D. (2006). 'The National Biosolids
Research Program: Research Studies on the Impact of Heavy Metals on Sustainable Fertilisation and the Intensive Agricultural Applications of Biosolids', Final Report to the Water Corporation of Western Australia, December 2006, Contract XX-03-11200.

Pritchard D.L. (2005). Phosphorus bioavailability in land applied biosolids in south-western Australia, PhD Thesis, Muresk Institute, Curtin University of Technology, Western Australia.

Pritchard D. L. and Penney N. (2003). Validation of land application biosolids in W.A. through innovative research. Proceedings: 'Innovations in Water' Ozwater Convention and Exhibition, Perth, WA, April 6-10 2003, Australian Water Association, Artarmon, N.S.W.

Rigby H., Pritchard D. and Collins D. (2008). 'Research Studies on the Impact of the Agricultural Application of Alum Dosed Biosolids', Progress Report to the Water Corporation of Western Australia, December 2008, Contract CN-07-13674.

Wagner D.J., Elliott H.A., Brandt R.C. and Jaiswal D. (2008) Managing biosolids runoff phosphorus using buffer strips enhanced with drinking water treatment residuals. Journal of Environmental Quality, 37:1567-1574.

Warne M.St.J., Heemsbergen D.A., Stevens D., McLaughlin M.J., Cozens G., Whatmuff M., Broos K., Barry G., Bell M., Nash D., Pritchard D. and Penney N. (2008). Modelling the toxicity of $\mathrm{Cu}$ and $\mathrm{Zn}$ salts to wheat in fourteen soils. Environmental Toxicology and Chemistry, 27(4), 786-792. 